\title{
Comparison of Methods Used for Evaluation of Mutagenicity/Genotoxicity of Model Chemicals - Parabens
}

\author{
Jan CHRZ ${ }^{1,2}$, Barbora HOŠÍKOVÁ ${ }^{2}$, Lada SVOBODOVÁ ${ }^{1,2}$, Danuše OČADLÍKOVÁ ${ }^{1}$, Hana \\ KOLÁŘOVÁ ${ }^{2}$, Markéta DVOŘÁKOVÁ ${ }^{1}$, Kristina KEJLOVÁ ${ }^{1}$, Lukáš MALINA ${ }^{2}$, Gabriela \\ JÍROVÁ ${ }^{1,3}$, Alena VLKOVÁ ${ }^{1,3}$, Marika MANNERSTRÖM ${ }^{4}$ \\ ${ }^{1}$ National Institute of Public Health, Centre of Toxicology and Health Safety, Prague, Czech \\ Republic, ${ }^{2}$ Department of Medical Biophysics, Institute of Molecular and Translational Medicine, \\ Faculty of Medicine and Dentistry, Palacky University in Olomouc, Czech Republic, ${ }^{3}$ Faculty of \\ Environmental Sciences, Czech University of Life Sciences Prague, Czech Republic, ${ }^{4}$ FICAM, \\ Faculty of Medicine and Health Technology, Tampere University, Tampere, Finland
}

Received October 29, 2020

Accepted November 10, 2020

\section{Summary}

Growing worldwide efforts to replace (reduce) animal testing and to improve alternative in vitro tests which may be more efficient in terms of both time, cost and scientific validity include also genotoxicity/mutagenicity endpoints. The aim of the review article was to summarize currently available in vitrotesting approaches in this field, their regulatory acceptance and recommended combinations for classification of chemicals. A study using the combination of Comet Assay performed on two cell lines and the Chromosomal Aberration test on human peripheral lymphocytes was performed with the aim to predict the genotoxic potential of selected paraben esters, serving as a model chemical group. Parabens are widely used in consumer products as preservatives and have been reported to exhibit inconclusive results in numerous genotoxicity studies. The Comet Assay identified Ethylparaben and Benzylparaben as potentially genotoxic. The Chromosomal Aberration test revealed weak genotoxic potential in case of Ethylparaben and positive genotoxicity in case of Butylparaben, Propylparaben and Isopropylparaben. The main reasons for variability seem to be limited water solubility of parabens, determining their bioavailability at the cellular level, and absence of metabolic activation in the Comet Assay. The results confirmed that the Comet Assay should serve as a screening test and should not be used as a stand-alone method for classification of genotoxicity. The weight of evidence approach in risk assessment should be supported with data generated with the use of human relevant in vitro methods based on cells / tissues of human origin.

\section{Key words}

Genotoxicity • Mutagenicity • Alternative Toxicological Testing • in vitro Methods • Test Batteries • Parabens

\section{Corresponding author}

J. Chrz, National Institute of Public Health, Centre of Toxicology and Health Safety, Šrobárova 49/48, 10000 Prague, Czech Republic. E-mail: jan.chrz@szu.cz

\section{Introduction}

Genotoxicity is one of the most critical toxicological endpoints, highly relevant for public health and environmental protection, including the safety of consumers. The principles of the 3Rs, defined as Replacement, Reduction and Refinement of animal testing by Russell and Burch (1959), represent the ethical basis for the use of laboratory animals in research projects. The Council Directive 2010/63/EU on the protection of animals strongly supports efforts to find alternative methods to animal testing (Beken et al. 2016, Directive 2010/63). Numerous in vitro testing approaches have been developed with the use of preferentially human relevant biological systems, which often consist of human derived tissue cultures or cell lines (OECD 2017). Unfortunately, the acceptance of in vitro toxicological methods alternative to animal testing for genotoxicity endpoints lags behind the progress in technological 
development and animal tests remain to be required (Kerecman et al. 2017, Coleman et al. 2012). Despite of numerous guidelines and publications, considering the benefits of the $3 \mathrm{Rs}$ for both animals and science, and substantial advances in the development, validation, and employment of alternative non-animal methods, scientists traditionally tend to prefer the use of animal-based approaches (Combes and Balls 2014). Difficulties in evaluation of in vitro genotoxicity endpoints, particularly the physiological background of induction, manifestation and persistence of the genotoxic effects, and also difficulties in transposing and linking the in vitro results to in vivo conditions may be suggested as the reasons of low acceptance of in vitro data. However, a few in vitro tests have been already accepted for regulatory purposes, i.e., in vitro mammalian chromosomal aberration test (OECD TG 473), In vitro mammalian cell micronucleus test (TG 487), and Bacterial reverse mutation test in Salmonella typhimurium and Escherichia coli (Ames test) (TG 471). Furthermore, in vitro systems have been included into OECD TGs designed originally for in vivo conditions, e.g. the in vivo Mammalian Alkaline Comet Assay considers in vitro systems to be useful for further investigation of genotoxicity (OECD 2016d). In order to classify a substance as non-genotoxic, a combination of appropriate in vitro technologies should be employed (Kerecman et al. 2017). Individual in vitro methods may exhibit specific advantages and limitations, while their combination may increase sensitivity of safety evaluation (Bhagat 2018). Nevertheless, so far no single in vitro test allows detection of the wide range of specific changes in the DNA structure manifested as adverse effects associated either with genotoxicity or mutagenicity (Nesslany 2017). Therefore, combinations of 2 or 3 validated in vitro tests of sufficient sensitivity and specificity are currently recommended to be used. Chemical substances may be evaluated as showing no genotoxic potential if all in vitro endpoints used are clearly negative while at least two in vitro endpoints showing positive results may predict genotoxic potential (EFSA 2011). International working groups and experts from OECD, EURL ECVAM, EPAA, ICCVAM, etc., have been involved in promotion and validation of alternative toxicological methods for regulatory acceptance to replace, reduce or refine (3Rs) in vivo testing. Additional data are needed, particularly related to toxicological mechanisms and absorption, distribution, metabolism and excretion (ADME) properties. The development of new approach methodologies (e.g. the development of the OECD QSAR Toolbox, supported by the European Chemical Agency ECHA) should bring high throughput assessment methods, supporting current alternative approaches with human relevant information. Scientific recommendations of testing approaches, and combinations of in vitro and in vivo methods, have resulted in binding legislation or non-binding recommendations, e.g.: the constantly updated Council regulation (EC) No 440/2008 laying down test methods pursuant to Regulation (EC) No 1907/2006 (REACH) (EC 2008), OECD Overview on Genetic Toxicology TGs (OECD 2017), ECHA Report on Non-animal Approaches - Current Status of Regulatory Applicability under the REACH, CLP and Biocidal Products Regulations (ECHA 2017), EFSA Statement on Genotoxicity Assessment of Chemical Mixtures (EFSA 2018) and EFSA Scientific Opinion on Genotoxicity Testing Strategies Applicable to Food and Feed Safety Assessment (EFSA 2012).

\section{In vitro approaches available for genotoxicity testing}

In vitro endpoints which may be manifested as adverse effects in vivo include changes in DNA structure, i.e. numerical chromosomal aberrations (aneuploidy), structural changes (clastogenicity), (double) strand breaks, translocations, deletions, point mutations, gaps, etc. (Turkez et al. 2017). A test battery designed for initial screening of genotoxic potential should allow detection of three important genotoxic endpoints, i.e., gene mutations, structural chromosomal aberrations i.e., clastogenicity, and numerical chromosomal aberrations (aneuploidy), in order to understand the genotoxic mode of action (genotoxic endpoint) of the tested substance (EFSA 2011). in vitro cell systems mostly included in the OECD TGs, such as mouse lymphoma cells L5178Y, CHO-AS52 and V79 cell lines have been derived from laboratory animals. However, human relevant cell lines derived from malignant cells, such as the e.g. TK6 human lymphoblastoid cells, have been recommended to be used for in vitro testing OECD TG 473, 476, 490 (EFSA 2011, OECD 2016b, Ranganatha et al. 2016, OECD 2015).

In vitro mammalian cell gene mutation test using the thymidine kinase gene has been recently included into the OECD TG 490 database (OECD 2016e) to identify substances potentially causing gene mutations at the thymidine kinase $(t k)$ reporter locus (OECD 2015). The use of in vitro systems has indeed been seriously considered useful and included in updated OECD Test Guidelines, such as the OECD TG 489 (In vivo Mammalian Alkaline Comet Assay). 
The most commonly used methods to assess the genotoxic potential of substances in vivo, with possible inclusion of in vitro test systems are listed below, on the basis of their principal endpoint of genotoxicity:

\section{Gene mutations:}

- Transgenic rodent somatic and germ cell gene mutation assays (OECD TG 488).

\section{Chromosome damage:}

- Mammalian erythrocyte micronucleus test (OECD TG 474),

- Mammalian bone marrow chromosome aberration test (OECD TG 475).

\section{Primary DNA damage:}

- in vivo mammalian alkaline Comet assay (OECD TG 489)

Toxicological test methods designed exclusively as in vitro approaches have been developed to be used for detection of the relevant genotoxic endpoints:

\section{Mutations:}

- Bacterial reverse mutation test in Salmonella typhimurium and Escherichia coli (Ames test) (OECD TG 471),

- in vitro mammalian cell gene mutation test (OECD TG 476),

- in vitro gene mutation assays using the $t k$ locus (OECD TG 490).

Chromosome aberrations:

- in vitro mammalian chromosomal aberration test (OECD TG 473),

- in vitro mammalian cell micronucleus test (OECD TG 487) (clastogenicity),

- $\quad$ in vitro mammalian alkaline Comet assay (performed with the use of in vitro test system, in compliance with OECD TG 489) (strand breaks).

The most widely used tests include Bacterial reverse mutation test (OECD TG 471), in vitro mammalian cell micronucleus test (OECD TG 487) and in vitro mammalian chromosome aberration test (OECD 473).

The Bacterial reverse mutation test (Ames test) has been designed to evaluate the mutagenic potential of test chemicals or mixtures. Ames test is generally used as the first screening method to assess genotoxicity and detection of gene mutations (Bhagat 2018). The assay is based on specific strains Salmonella typhimurium and Escherichia coli containing identified mutations in amino acid biosynthesis genes at the reporter locus (i.e., histidine [His] or tryptophan [Tryp], respectively) (OECD 1997, OECD 2015). The test detects mutations which revert the identified mutations in the test strains. The revertants are identified by their restored functional capability to synthesize a specific amino acid. The limitation of this method is the use of prokaryotic cells which differ from mammalian cells in factors such as uptake, metabolism, chromosome structure and DNA repair processes. There have been developments to use it in high throughput screening (Flückiger-Isler et al. 2004) but the methods have not been developed to a point where they can be routinely used. Substances not directly interacting with DNA may not be detected as mutagenic, which may be relevant especially for substances that have been shown to decrease genomic stability by indirect mechanisms, such as DNA repair systems, cell cycle control and apoptosis (EFSA 2011).

The in vitro mammalian cell micronucleus test (MN) has been used for evaluation of cytogenetic damage for decades (Morita et al. 1997) in numerous types of test systems, including rodent bone marrow or peripheral blood lymphocytes (Benigni et al. 2012, Morita et al. 2016, Soeteman-Hernández et al. 2016) to identify chemical substances that cause primarily structural chromosomal damage (Corvi et al. 2008). The assay detects micronuclei in the cytoplasm of interphase cells and typically employs human or rodent cells lines or primary cell cultures (OECD 2016c). The MN test is almost as sensitive as the chromosomal aberration test (CA) for the detection of clastogens and has the additional advantage of detecting aneugenic substances. The in vitro $\mathrm{MN}$ test detects the fragments of chromosomes formed into micronuclei, whereas the chromosomal aberration test records visible numerical changes (aneuploidy), translocations and other complex chromosomal rearrangements, that may provide additional mechanistic information (Corvi et al. 2008, Kimura et al. 2013). Automated systems used for measuring the frequency of micronucleated cells include approaches of flow cytometry (De Boeck et al. 2005, Dertinger et al. 2011), fluorescent microscopy and image analysis (Parton et al. 1996), or laser scanning cytometry (Styles et al. 2001). The in vitro mammalian cell micronucleus test (OECD TG 487) can be conducted in 
the presence or in the absence of cytochalasin B (cytoB), which is used to block cell division and generate binucleated cells and may be combined e.g. with kinetochore staining or fluorescence in situ hybridisation (FISH) (EFSA 2011).

The in vitro mammalian chromosome aberration test, based on a proliferating cell population of established cell lines or primary cell cultures in metaphase (Bhagat 2018, OECD 2015), has been used for decades as a biomarker of the early effects of genotoxic carcinogens (Norppa et al. 2006, Güzel Bayülken et al. 2019). The assay primarily allows the detection of structural aberrations of chromosomes, resulting in specific numerical chromosome aberrations (aneuploidy) in cultured mammalian cells. Additional mechanistic information can be provided using FISH or advanced chromosome staining techniques.

Increasing number of scientific studies have criticized the human relevance of using laboratory animals (e.g. rodents, as the preferred animal model) for assessing hazard and risk of chemicals in humans, as it has become scientifically debatable after consideration of data generated with the use of molecular biology approaches (Phalen et al. 2008, Creton et al. 2010, Chamanza and Wright 2015, Mowat et al. 2017).

The following laboratory animals have been conventionally recommended to be used for genotoxicity testing or as a primary source of in vitro cell systems:

- Chinese hamster (Mesocricetus auratus) in the Syrian Hamster Embryo (SHE) cell transformation test, Chinese hamster ovary (CHO) and Chinese hamster lung (CHL) cells

- Deer mouse (Peromyscus leucopus, Peromyscus maniculatus) (He and Toth 2017)

- Laboratory mouse (Mus musculus var. alba)

- $\quad$ Rat (Rattus rattus), (Rattus norvegicus var. alba)

Rodent cell lines currently used in genotoxicity tests may exhibit specific deficiencies. $\mathrm{CHO}$ cells have been reported to carry a mutant $\mathrm{p} 53$ sequence and lack of G1 checkpoint; CHL cells have been reported to exhibit altered regulation of p53 expression; V79 and L5178Y mouse lymphoma cells were found to synthesize a dysfunctional p53 protein (Chaung et al. 1997, Storer et al. 1997). These issues may increase the test sensitivity, but, in return, induce false positive results (Kirkland et al. 2011). The specific cell type used in the bioassay may strongly affect the cellular response and in vitro predictivity (Fowler et al. 2012). The deficiencies and limits of rodent cell lines have led to efforts to develop and prefer in vitro systems based on cells of human origin, which are efficient for DNA repair and for p53 (Kirkland et al. 2005, Kirkland et al. 2007, Nesslany 2017). An increasing number of studies based on human relevant in vitro systems, have demonstrated promising results, indicating significant sensitivity and specificity of the novel approaches. Computational modeling approaches have been suggested for predicting the genotoxic potential and carcinogenicity of chemicals, and have been included in testing strategies in pharmacology (Wu and Wang 2018). Human derived reconstructed 3D epithelium tissue models (RhE) consisting of reconstructed epidermis and functional stratum corneum have been used to establish novel in vitro human reconstructed skin micronucleus (MN) and Comet (CMT) assays designed to measure genotoxicity endpoints induced in dividing human keratinocytes after dermal exposure (Kirsch-Volders et al. 2011, Reisinger et al. 2018, Roy et al. 2016, Pfuhler et al. 2020a, Pfuhler et al. 2020b). Examples of three-dimensional organ models, multicellular spheroids of liver cells (Xu et al. 2003) and bone marrow cell cultures (Dal Negro et al. 2006) as well as novel technologies using human organ models on-achip have been recently introduced (Andersen et al. 2014, Alépée et al. 2014, Marx et al. 2016) with the aim to maximally mimick physiological conditions (Rossini and Hartung 2012). Experimental studies have used e.g. exfoliated oral epithelium cells from buccal smears of healthy donors in the micronucleus test. Buccal smears have been reported as a valuable source of primary cells, however, of limited standardization (Bortoluzzi et al. 2014, Jyoti et al. 2012, Jyoti et al. 2015). For routine in vitro toxicological testing, standardized (non-malignant) cell lines may provide more relevant response in standardized conditions. Human bronchial epithelial cell line BEAS-2B was used for detection of genotoxicity of engine emissions in in vitro $\mathrm{MN}$ assay (Cervena et al. 2017). Human derived cell lines that have been used in MN assay include primary human lymphocytes, lymphoblastoid cell line TK6, HepaRG cell line, HT29 (Human colon cancer cell line), Caco-2 cell line (Human heterogenous epithelial colorectal adenocarcinoma), HepG2 (hepatocellular carcinoma) (Allemang et al. 2018, Wieczerzak et al. 2019, Puerto et al. 2018, McCarrick et al. 2019). Primary human peripheral lymphocytes have been found to potentially generate fewer false positive results than e.g. V79, L5178Y and TK6 cells (Kirkland et al. 2007, OECD 2015). However, not all the systems 
have been extensively validated so far, and their use is recommended only if their performance meets the acceptance criteria. Conflicting data have been often obtained in genotoxicity studies, depending on the substances analyzed and methods used, indicating low analytical sensitivity to fully cover the complex causation of genotoxicity, mutagenicity and carcinogenicity. Comparison of the results may be compromised by variability in practical procedure steps or test systems used. Therefore, combinations of toxicological methods (in vitro, in vivo) have been proposed in order to increase the sensitivity of genotoxicity testing.

Combinations of methods recommended for genotoxicity/mutagenicity/carcinogenicity testing

Combinations of tests for the screening of carcinogenicity were proposed already in 1974 (Stoltz et al. 1974). Most recently, the combination of Ames test, in vivo $\mathrm{MN}$, in vivo $\mathrm{CA}$ and $\mathrm{CMT}$ assay has been reported to increase the sensitivity of a testing battery proposed for detection of carcinogens (Kang et al. 2013a, Kim and Margolin 1999, Morita et al. 2016), alternatively the combination of Ames test and in vivo $\mathrm{MN}$ has been also reported to show promising sensitivity (Shelby and Zeiger 1990) or combination of MN and CMT assays (Recio et al. 2010, Vasquez 2010, Kang et al. 2013a). Significant sensitivity was suggested for combination of in vivo CMT (90\%) and in vitro CMT (86.9\%), in vivo $\mathrm{MN}+$ in vivo $\mathrm{CA}(88.6 \%)$, in vivo $\mathrm{MN}+$ in vivo $\mathrm{CMT}$ (92.5\%), in vitro CMT + in vivo $\mathrm{MN}$ (95.6\%) (Bhagat 2018, Kimura et al. 2013). The highest sensitivity has been observed in combination of in vivo $\mathrm{CMT}+$ in vivo CA (96.7\%) (Bhagat 2018, Madrigal-Bujaidar et al. 2008, Pfuhler et al. 2009, Bowen et al. 2011). However, the general development of toxicological testing, performed according to the $3 \mathrm{R}$ principles, allows the inclusion of exclusively in vitro endpoints in suitable combinations into testing batteries without the use of animals. Assuming that a stand-alone single in vitro test cannot be expected to predict all key events potentially resulting in persistent genotoxicity and/or mutagenicity, the combination of in vitro assays should include tests with sufficient sensitivity (in order to avoid false negative results) and specificity (in order to avoid false positive results). A standard battery of in vitro genotoxicity tests, recommended to be suitable for regulatory purposes, should include 2 or 3 validated tests with at least one test on bacteria and one test on cell cultures (Nesslany 2017). The complex aspects of the induction and causation of the adverse effects, representing potential connections between genotoxicity, mutagenicity and carcinogenicity have to be deeply considered. Genotoxicity has been referred to as an induced damage to DNA, including alterations of the DNA structure, information content and segregation, without direct connection to mutagenicity. Therefore, in vitro genotoxicity testing was recommended to include tests detecting DNA strand breaks, DNA adduct formation or mitotic recombination, in addition to specific tests for mutagenicity (Dearfield et al. 2011, EFSA 2011, UK Committee on Mutagenicity COM 2011).

Exclusive in vitro approaches are strongly recommended in case of dermal exposure and are the only available testing approaches in case of cosmetics and cosmetic ingredients. In case of cosmetic ingredients, the evaluation of the potential for mutagenicity to be annexed in the Regulation (EC) No 1223/2009 should include tests to provide information on three genotoxic endpoints, i.e.: mutagenicity at the gene level, chromosome breakage and/or rearrangements (clastogenicity) and numerical chromosome aberrations (aneuploidy).

The European Scientific Committee on Consumer Safety recommended two tests for the base level testing of cosmetic ingredients, represented by the following test systems:

- Bacterial Reverse Mutation Test (OECD 471) as a test covering gene mutations,

- In vitro Micronucleus Test (OECD 487) as a test for both structural (clastogenicity) and numerical (aneugenicity) chromosome aberrations.

Confirmative or supportive evidence may be obtained with the use of tests detecting primary DNA damage (Kirkland et al. 2011).

\section{Metabolic activation}

Certain chemicals may exhibit genotoxicity only after metabolic activation (indirect genotoxins), therefore it is recommended to include metabolic activation system (MAS) to mimic the situation in vivo (Tice et al. 2000, Nesslany 2017). Cultivation in vitro without MAS may lead to downregulation of enzyme genes and low function of detoxification systems involved in reduction of reactive oxygen species (Oesch et al. 2019). The most common system used for metabolic activation is the S9 fraction, prepared traditionally from the liver of rodents (usually rats), but nowadays also human S9 fractions are 
commercially available (EFSA 2011, Hong et al. 2018). S9 fraction has, however, been reported to compromise the in vitro results, as the efficacy of metabolic activation may be specific (depending on e.g. age or sex) and cytotoxicity or variable mutagenic response may be observed (Nishimuta et al. 2013, Cox et al. 2016, Tweats et al. 2007a). Moreover, S9 fractions lack cellular compartmentalization and transporter functions. Human HepaRG cell line, instead, exhibit major CYP activities and other liver specific functions comparable to primary hepatocytes, and has unique potential for competent metabolic activation and may be used as the source of MAS (Josse et al. 2012).

\section{Aim of the study}

More data from the use of in vitro bioassays and test systems are necessary to be generated in order to evaluate the predictivity, sensitivity and specificity of alternative methods suitable for genotoxicity assessment, as still a limited amount of data has been available. Therefore, we carried out a study using the combination of CMT (Comet) assay performed using two nonmalignant keratinocyte cell lines $\mathrm{HaCaT}$ and SVK14, and the CA (Chromosomal aberration) test using human peripheral lymphocytes, with the aim to predict the genotoxic potential of selected paraben esters, used as a model chemical group. Parabens are widely used in consumer products as preservatives and have been reported to exhibit inconclusive results in numerous genotoxicity studies. We describe the advantages and limits of the combined in vitro approaches and also introduce practical issues and details which may help to develop a standardized approach.

\section{Materials and Methods}

\section{Tested chemicals}

Paraben esters (methylparaben, ethylparaben, propylparaben, isopropylparaben, butylparaben, isobutylparaben, benzylparaben) were supplied from (TCI) TOKYO Chemical industry CO., LTD and used as test substances (Table 1).

\section{Cell lines and culture conditions}

Commercially available non-tumor cell lines derived from human keratinocytes, i.e. HaCaT cell line and SVK14 cell line (both from ATCC, USA) were used in the in vitro CMT assay. For the CA assay, human peripheral blood was obtained by venepuncture from a healthy female human volunteer (non-smoker, nondrinker who was not exposed to radiation, infections or medication for less than one month before the date of collection). The study, performed in compliance

Table 1. Tested chemicals and their formulas.

\begin{tabular}{|c|c|c|c|c|c|}
\hline Substance & IUPAC Name & CAS & Formula & $\begin{array}{c}\text { Structural } \\
\text { Formula }\end{array}$ & $\begin{array}{c}\text { Molecular } \\
\text { weight }\end{array}$ \\
\hline Methylparaben & methyl 4-hydroxybenzoate & $99-76-3$ & $\mathrm{C}_{8} \mathrm{H}_{8} \mathrm{O}_{3}$ & & 152.15 \\
\hline Ethylparaben & ethyl 4-hydroxybenzoate & $120-47-8$ & $\mathrm{C}_{9} \mathrm{H}_{10} \mathrm{O}_{3}$ & & 166.17 \\
\hline Propylparaben & propyl 4-hydroxybenzoate & $94-13-3$ & $\mathrm{C}_{10} \mathrm{H}_{12} \mathrm{O}_{3}$ & & 180.21 \\
\hline Isopropylparaben & $\begin{array}{l}\text { propan-2-yl 4- } \\
\text { hydroxybenzoate }\end{array}$ & $4191-73-5$ & $\mathrm{C}_{10} \mathrm{H}_{12} \mathrm{O}_{3}$ & & 180.20 \\
\hline Butylparaben & butyl 4-hydroxybenzoate & $94-26-8$ & $\mathrm{C}_{11} \mathrm{H}_{14} \mathrm{O}_{3}$ & & 194.23 \\
\hline Isobutylparaben & $\begin{array}{l}\text { 2-methylpropyl 4- } \\
\text { hydroxybenzoate }\end{array}$ & $4247-02-3$ & $\mathrm{C}_{11} \mathrm{H}_{14} \mathrm{O}_{3}$ & & 194.23 \\
\hline Benzylparaben & benzyl 4-hydroxybenzoate & $94-18-8$ & $\mathrm{C}_{14} \mathrm{H}_{12} \mathrm{O}_{3}$ & & 228.25 \\
\hline
\end{tabular}


with the WMA Declaration of Helsinki - Ethical Principles for Medical Research Involving Human Subjects (1964, amended 2013) and the International Ethical Guidelines for Health-related Research Involving Humans (CIOMS 2016), was approved by the Ethical Review Committee of the National Institute of Public Health.

\section{MTT assay}

The in vitro cytototoxic effect of the parabens used on the two cell lines SVK14 and HaCaT (both human keratinocytes; ATCC, USA) was measured by MTT assay (Mosmann, 1983). Each paraben (diluted in DMEM) was applied to cells at selected concentrations and incubated for 24 hours. After incubation, DMEM (Sigma Aldrich, USA) was replaced by a solution containing $50 \mu \mathrm{l}$ of $0.5 \mathrm{mg} \mathrm{ml}^{-1}$ MTT (Sigma Aldrich, USA) dissolved in $1 \mathrm{x}$ PBS. Afterwards, the cell lines were incubated with MTT for 4 hours at $5 \% \mathrm{CO}_{2}$ and $37{ }^{\circ} \mathrm{C}$. The MTT solution was then replaced with $100 \mu \mathrm{l}$ of DMSO to ensure the formazan crystals to be properly dissolved. The absorbance level was measured by a Tecan Infinite Pro200 reader (Tecan, Switzerland).

\section{In vitro Comet assay (CMT)}

The method was used based on OECD TG 489 with modifications, i.e. using human relevant non-tumor cell lines derived from human keratinocytes (Jiravova et al. 2016). Test substances at pre-tested selected concentrations in DMEM were applied to the cell culture for 24 hours. As a positive control, $1 \% \mathrm{H}_{2} \mathrm{O}_{2}$ in PBS was applied to the cell culture for 15 minutes at $4{ }^{\circ} \mathrm{C}$. Culture medium (DMEM) served as negative control. After incubation, cells were harvested using TrypLE (Gibco, 12604-021) for +/- $10 \mathrm{~min}$. DMEM with fetal bovine serum was applied to stop the trypsinization. Harvested cell suspension was centrifuged and the cell pellet was collected. A $1 \%$ low melting point (LMP) agarose solution, tempered at $37{ }^{\circ} \mathrm{C}$, was mixed with the cell pellet. The resulting dense agarose suspension was pipetted onto pre-coated microscopic slides and quickly covered with coverslips. The agarose was solidified at $4{ }^{\circ} \mathrm{C}$ in the refrigerator and then the coverslips were carefully removed, preventing the damage of the sample. Slides were immersed in lysis buffer with $1 \%$ Triton $\mathrm{X}-100$ and incubated in glass Coplin Jars for 60 minutes at $4{ }^{\circ} \mathrm{C}$ in order to ensure sufficient cell lysis. In the next step, slides were placed in an electrophoretic tank (SubCell Model 192 Cell, 2,000 ml) and embedded in sufficient volume (slightly covering the slides) of chilled $\left(4{ }^{\circ} \mathrm{C}\right)$ alkaline electrophoretic solution for 40 minutes. Electrophoresis was performed under the following conditions: $350 \mathrm{~mA}, 0.8 \mathrm{~V} \mathrm{~cm}^{-1}$, for 20 minutes. After electrophoresis, slides were carefully transferred and rinsed twice for 10 minutes with neutralization buffer $\left(\mathrm{pH} 7.5,4{ }^{\circ} \mathrm{C}\right)$. The slides were stained with SYBR Green I and evaluated microscopically using a fluorescence microscope with a CCD camera (Olympus). The experiment was repeated in three runs in triplicates. From each sample, 100 cells were selected for evaluation using the CometScore 1.5 software. The median values from each measurement were used for mathematical and statistical analysis, and mean values of the amount of DNA in the head of the comet (directly proportional to the intact, non-fragmented DNA), the Olive momentum and DNA in the tail were evaluated. The values of the DNA in the head of the comet were used for interpretation of results. Analysis of variance (ANOVA) and Dunnett $t$-tests were used for statistical analysis. A $p$ value $<0.05$ was used as the level of statistical significance. All statistical analyzes were performed using IBM SPSS Statistics for Windows, version 23.0. Armonk, NY: IBM Corp.

In vitro mammalian chromosome aberration test (CA)

The test was performed in accordance with OECD TG 473 (OECD 2016a). Peripheral blood lymphocytes were collected from a healthy donor and cultured in RPMI-1640 medium with L-glutamine and $\mathrm{NaHCO}_{3}$ (SIGMA) supplemented with $10 \%$ heatinactivated bovine serum (Bioveta, Czech Republic). Exogenous source of metabolic activation system (MAS), i.e. a cofactor-supplemented post-mitochondrial fraction prepared from rodent livers (Wistar rats, males, 7-8 weeks old) treated with an enzyme-inducing agent (polychlorinated biphenyl Delor), was used to model mammalian metabolic activation. Cells were exposed to the test substances with or without MAS. 48 hours after the start of the culture, the cells were treated for 4 hours with the test substance and positive control chemicals (Thio-TEPA $10^{-6} \mathrm{M}$ without MAS and cyclophosphamide $10^{-4} \mathrm{M}$ with MAS) and cultured for 24 hours. Culture medium was used as negative control. Then, the cell cultures were exposed for 2 hours to a metaphase arresting agent (colchicine), harvested and subjected to hypotonic cell treatment, fixation, and staining (5\% Giemsa). Metaphase cells (at least 200 well-spaced metaphases with $46 \pm 2$ centromeres) were analyzed 
microscopically for the presence of chromosomal aberrations. Gaps were recorded separately and were not included in the total frequency of aberrations. The percentage of cells with structural chromosomal aberrations was evaluated. At least a 2-fold increase in aberration cells compared to the negative control was a criterion for determining a positive result including a concentration-related increase in the number of cells with chromosomal aberrations.

\section{Results}

\section{MTT assay}

The results of MTT assay have shown concentration-dependent responses of all samples (Fig. 1, 2). Variability was observed in the used two in vitro test systems. Methylparaben was shown to exhibit the weakest cytotoxicity, as the detected cytotoxic concentration (below IC50 value) was $750 \mu \mathrm{g} / \mathrm{ml}$ in the $\mathrm{HaCaT}$ cell line and $500 \mu \mathrm{g} / \mathrm{ml}$ in the SVK14 cell line. Ethylparaben and Benzylparaben exhibited cytotoxicity at $500 \mu \mathrm{g} / \mathrm{ml}$ in both in vitro cell systems. Butylparaben exhibited cytotoxicity at $100 \mu \mathrm{g} / \mathrm{ml}$ in the HaCaT cell line and $500 \mu \mathrm{g} / \mathrm{ml}$ in the SVK14 cell line. Isobutylparaben and Propylparaben have shown similar results, as the detected cytotoxic concentration (below IC50 value) was $50 \mu \mathrm{g} / \mathrm{ml}$ for both Isobutylparaben and Propylparaben in the HaCaT cell line and $100 \mu \mathrm{g} / \mathrm{ml}$ in the SVK14 cell line. Isopropylparaben exhibited lower cytotoxicity in the SVK14 cell line, as the detected cytotoxic concentration (below IC50) was $500 \mu \mathrm{g} / \mathrm{ml}$, however, in the HaCaT cell line, the first cytotoxic concentration (below IC50) was $125 \mu \mathrm{g} / \mathrm{ml}$ (data not shown).
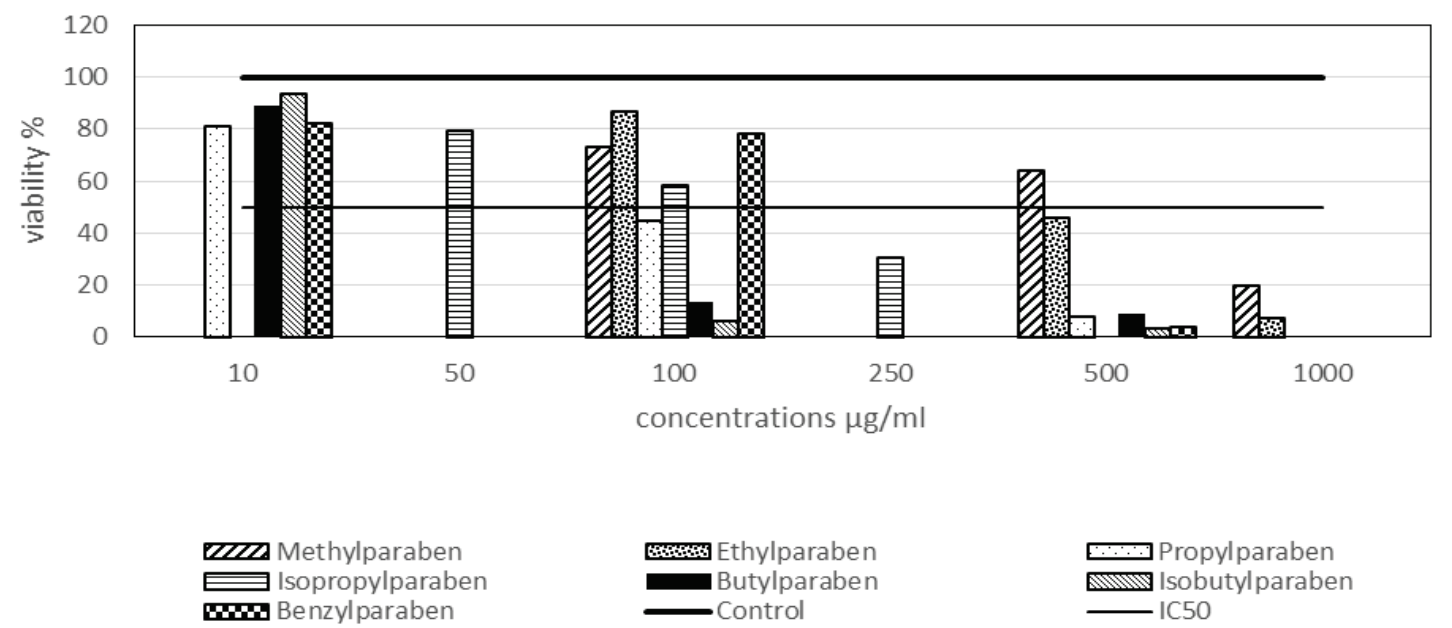

Fig. 1. MTT assay, HaCaT cell line. Bold full line represents the value of solvent control (100\%). Full line represents the cut-off value in comparison with solvent control (IC50).
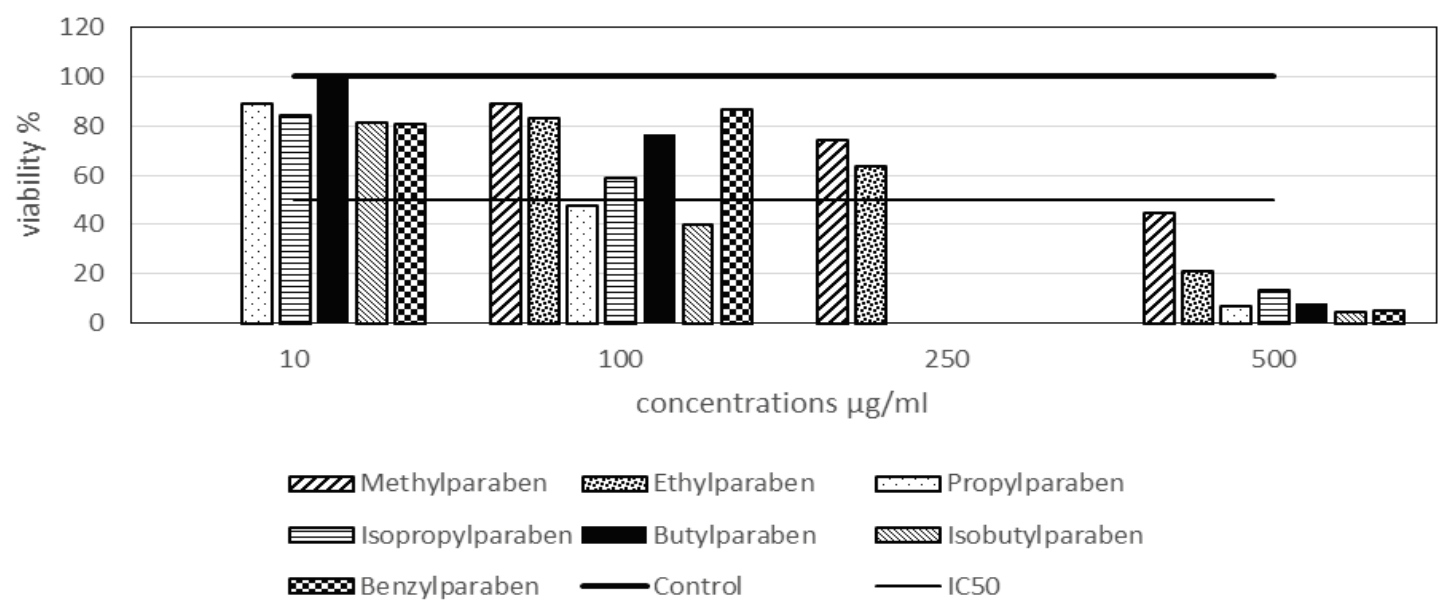

Fig. 2. MTT assay, SVK14 cell line. Bold full line represents the value of solvent control (100\%). Full line represents the cut-off value in comparison with solvent control (IC50). 
Comet assay in vitro in SVK14 cell line and HaCaT cell line

The observed intensity of DNA damage in the SVK14 cell line exposed to any of the parabens (Methyl-, Ethyl-, Propyl-, Isopropyl-, Butyl-, Isobutyl- or Benzylparaben) did not exceed the values of negative control even at high concentrations which were observed as cytotoxic in the MTT assay (Fig. 3). In the HaCaT cell line, Benzylparaben and Ethylparaben exhibited increased fragmentation of DNA (Benzylparaben, mean value $30.9 \%$ DNA in head at $250 \mu \mathrm{g} / \mathrm{ml}$; Ethylparaben, mean value $32.8 \%$ DNA in head at $1000 \mu \mathrm{g} / \mathrm{ml}$ ), which represented values significantly distant from the negative control (99.7\% DNA in head), whereas the fragmentation of DNA exceeded even the values of positive control $\left(0.1 \% \mathrm{H}_{2} \mathrm{O}_{2}\right.$ in $1 \mathrm{x} \mathrm{PBS}, 15 \mathrm{~min}, 4{ }^{\circ} \mathrm{C}$, mean value $62.9 \%$ DNA in head), as reported in Figure 4. Therefore, Benzylparaben and Ethylparaben were evaluated as suspected genotoxic substances in the in vitro Comet assay, as they may potentially exhibit genotoxic effects at higher concentrations. This result was used as an indication for further testing with the aim to confirm the results.

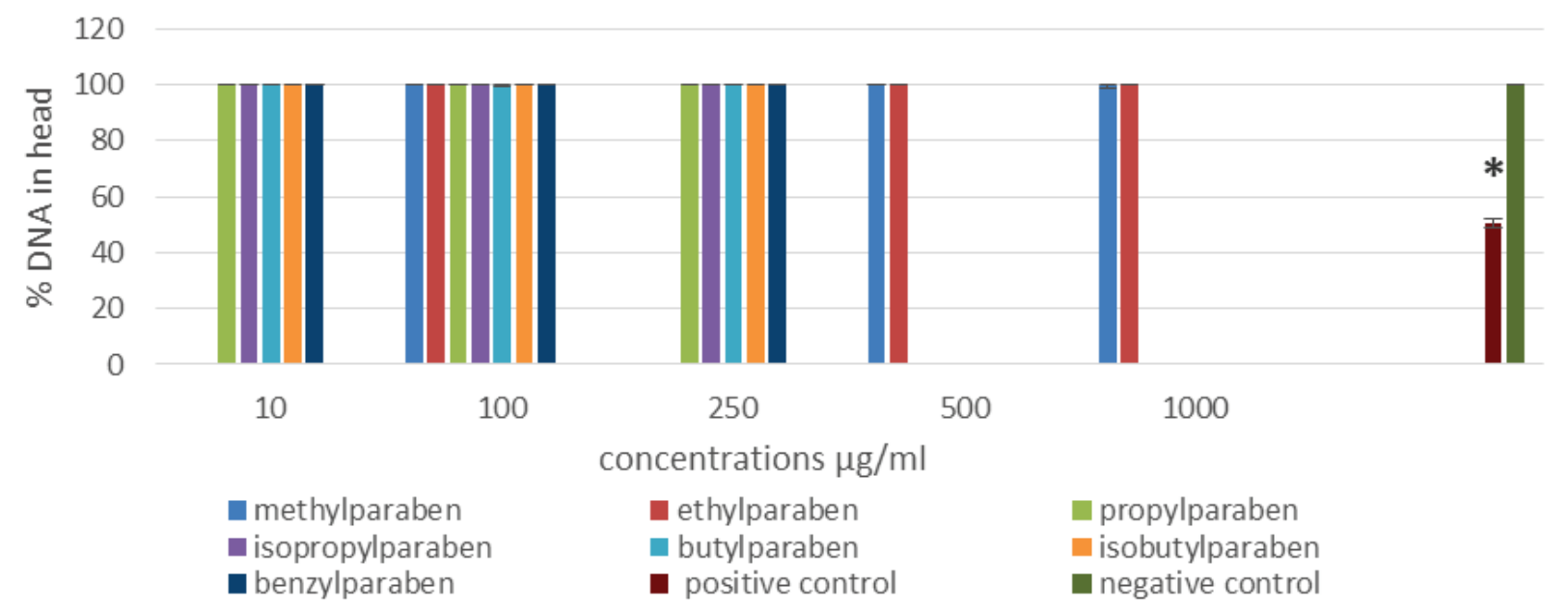

Fig. 3. Comet assay in vitro, SVK14 cell line. Data (\% DNA in head) are presented as median \pm SD values from three independent measurements. The results were considered statistically significant when $p<0.05(*)$. The DNA in head is proportional to the DNA damage (the higher value, the lower DNA damage).

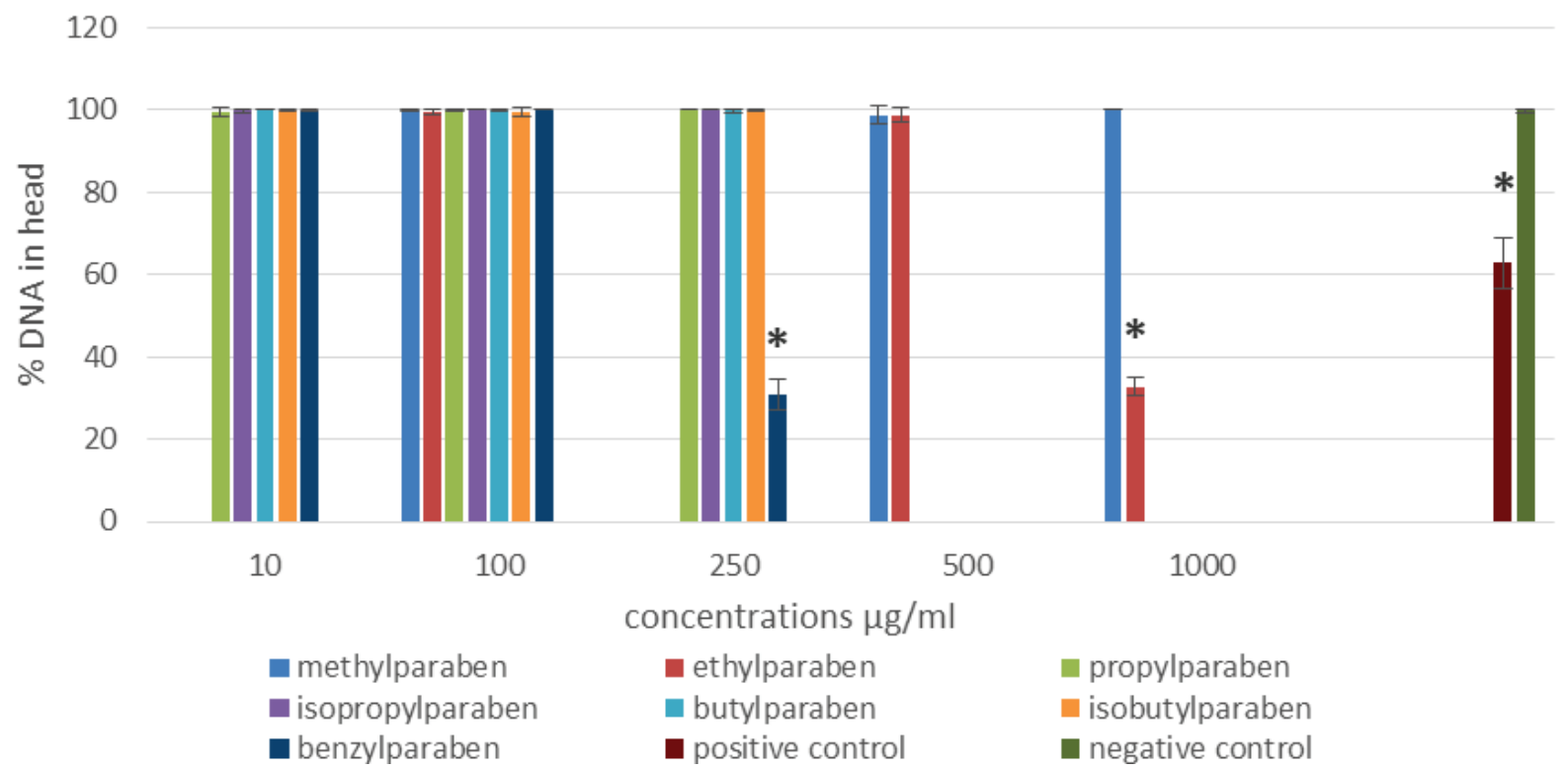

Fig. 4. Comet assay in vitro, HaCaT cell line. Data (\% DNA in head) are presented as median \pm SD values from three independent measurements. The results were considered statistically significant when $p<0.05\left(^{*}\right)$. The DNA in head is proportional to the DNA damage (the higher value, the lower DNA damage). 
Table 2. In vitro mammalian chromosome aberration test.

\begin{tabular}{|c|c|c|c|c|c|}
\hline \multirow[b]{2}{*}{$\begin{array}{l}\text { Samples / } \\
\text { Controls }\end{array}$} & \multicolumn{4}{|c|}{$\%$ abberant cells } & \multirow[t]{2}{*}{ Evaluation } \\
\hline & $\begin{array}{c}\text { Concentration } \\
\mu \mathrm{g} / \mathrm{ml}\end{array}$ & $\begin{array}{c}4 \mathrm{~h} \\
\text { with MAS }\end{array}$ & $\begin{array}{c}4 \mathrm{~h} \\
\text { without MAS }\end{array}$ & $\begin{array}{c}26 \mathrm{~h} \\
\text { without MAS }\end{array}$ & \\
\hline \multirow[t]{4}{*}{ Methylparaben } & 10 & 3 & 4 & 4.5 & negative \\
\hline & 25 & 4 & 3 & tox & $\begin{array}{l}\text { inconclusive result due to } \\
\text { cytotoxicity }\end{array}$ \\
\hline & 50 & tox & tox & tox & \\
\hline & 100 & tox & tox & tox & \\
\hline \multirow[t]{4}{*}{ Ethylparaben } & 10 & 3 & 3 & 3 & borderline \\
\hline & 25 & 5.5 & 4 & tox & $\begin{array}{l}\text { inconclusive result due to } \\
\text { cytotoxicity }\end{array}$ \\
\hline & 50 & tox & tox & tox & \\
\hline & 100 & tox & tox & tox & \\
\hline \multirow[t]{4}{*}{ Propylparaben } & 5 & 4 & 3.5 & 2.5 & positive \\
\hline & 10 & 2 & 3 & 2 & \\
\hline & 25 & 5 & 6 & 9 & \\
\hline & 50 & tox & tox & tox & \\
\hline \multirow[t]{4}{*}{ Isopropylparaben } & 5 & 3 & 3 & 2 & positive \\
\hline & 10 & 2.5 & 3 & 3.5 & \\
\hline & 25 & 4 & 4.5 & 7.5 & \\
\hline & 50 & tox & tox & tox & \\
\hline \multirow[t]{4}{*}{ Butylparaben } & 5 & 5 & 5 & 3 & positive \\
\hline & 10 & 6 & 5.5 & 9 & \\
\hline & 25 & tox & tox & tox & \\
\hline & 50 & tox & tox & tox & \\
\hline \multirow[t]{4}{*}{ Isobutylparaben } & 5 & 3 & 3 & 2.5 & negative \\
\hline & 10 & 5 & 4 & 4.5 & \\
\hline & 25 & tox & tox & tox & \\
\hline & 50 & tox & tox & tox & \\
\hline \multirow[t]{4}{*}{ Benzylparaben } & 1 & 4 & 3 & 2.5 & negative \\
\hline & 2.5 & 5 & 3 & 0.5 & \\
\hline & 5 & 2.5 & 4 & 1.5 & \\
\hline & 10 & 3.5 & 3 & 5 & \\
\hline \multicolumn{2}{|c|}{ Negative control (non-treated cells) } & & 3 & 2 & \\
\hline \multicolumn{2}{|c|}{ Positive control (thio-TEPA) } & & 10 & 15 & \\
\hline \multicolumn{2}{|c|}{$\begin{array}{l}\text { MAS Negative control } \\
\text { (non-treated cells with MAS) }\end{array}$} & 5.5 & & & \\
\hline \multicolumn{2}{|c|}{ Positive control (cyclophosphamide) } & 11 & & & \\
\hline
\end{tabular}

The percentage of aberrant cells is recorded after $4 \mathrm{~h}$ with/without MAS and $26 \mathrm{~h}$ without MAS (MAS - metabolic activation system). Due to the toxicity of the test substance at a given concentration, mitoses were not evaluable (designated tox).

In vitro mammalian chromosome aberration assay

In the validated in vitro mammalian chromosome aberration assay, human peripheral blood lymphocytes did not show an increased rate of chromosomal aberrations compared to the negative control for Methylparaben, Isobutylparaben and 
Benzylparaben. Ethylparaben was considered borderline, but due to its high toxicity it was not possible to evaluate the sample in all concentrations. Propylparaben, Isopropylparaben and Butylparaben had a high percentage of aberrations and the concentration dependence at the highest tested concentrations is evident compared to the negative control (more than 2-fold) in the case of the 26-hour incubation without MAS (Table 2).

\section{Discussion}

The aim of our study was to generate data with the use of two in vitro toxicological methods in combination, performed in three human relevant non-malignant cell systems. We performed the in vitro Comet assay using the HaCaT and SVK14 cell line and the CA assay using human peripheral blood lymphocytes. Our study demonstrated high variability of results between the two in vitro methods, and surprisingly also between the two cell lines used in the Comet assay. The observed intensity of DNA damage in the SVK14 cell line did not exceed the values of negative control and all the samples were classified as negative, indicating that the substances neither significantly accumulated in the DNA nor attacked the DNA structure, thus, their cytotoxicity may be attributed to other mechanisms than direct DNA damage. With the use of the $\mathrm{HaCaT}$ cell line, most samples were also classified as negative, however, Benzylparaben and Ethylparaben exhibited an increased fragmentation of DNA at one tested concentration. We considered the results from the Comet assay as indicative for further testing and performed a validated CA assay using human peripheral blood lymphocytes. In the CA assay, Methylparaben was classified as negative and Ethylparaben as borderline, however, both exhibited significant cytotoxicity. Propylparaben, Isopropylparaben, Butylparaben were classified as positive, and Isobutylparaben, Benzylparaben as negative. Comet assay has been repeatedly described in other studies to give positive results only at significantly higher concentrations than in the CA or MN test (Giannotti et al. 2002, Kimura et al. 2013, Kawaguchi et al. 2010). As the Comet assay may not give a specific response with satisfactory sensitivity at lower concentrations and lacks metabolic activation, or the CA test may be compromised by higher cytotoxicity, the two tests do not seem to correlate promisingly. Assuming that a negative in vitro result should be supported by data from at least two validated in vitro tests, and with regard that only one In vitro bioassay has been validated in our laboratory, the result has to be considered with caution. In case of inconclusive results from in vitro testing, repeating the test or applying another in vitro test is recommended (EFSA 2011). Unfortunately, increasing the number of In vitro assays may further reduce specificity and increase false positivity. Inconclusive results may be obtained due to inclusion of metabolic activation system, experimental conditions, specificities of the test system, cell type used, etc. (Nesslany 2017). Various mammalian cell types may exhibit variability in expression of genes involved in DNA repair, cellular defence systems, cell cycle control and apoptosis (e.g. p53), resulting in different response to chemicals. Lymphocytes have been reported to be karyotypically stable, however, when used in the CA test, mitogens have been observed to induce the resting phase. Characterization of in vitro test systems should be performed and donor-to-donor variation avoided (Tweats et al. 2007b). In order to deeply consider other possible sources of variability, we focused also on water solubility of parabens, determining their bioavailability at the cellular level. We also performed additional cytotoxicity test using $3 \mathrm{~T} 3 \mathrm{Balb} / \mathrm{c}$ fibroblasts and Neutral Red Uptake assay (3T3 NRU Cytotoxicity Assay), which was performed according to ECVAM DB-ALM Protocol no. 46 (data not published). Interestingly, during microscopic inspection, we observed various paraben-borne formations in the serum-free media, such as clusters or crystals, which were not observed during routine visual inspection. Moreover, the results of 3T3 NRU Cytotoxicity Assay have shown further variability. Therefore, we suggest that solubility in water solutions (i.e., culture media) should be thoroughly inspected in case of parabens, as poor water solubility or crystallization may significantly affect the bioavailability of parabens in both in vitro and in vivo test systems and compromise the results of genotoxicity testing. We performed a brief data search upon water solubility of parabens and found similar conclusions for individual parabens or their mixtures. Generally, parabens are stable in air and are resistant to hydrolysis in hot or cold water and in acidic solutions. The antibacterial potential of parabens increased with the length of esterified alcohol chain, however, the water solubility decreased (Soni et al. 2001). Variable antimicrobial potential and water solubility represents one of the reasons for application of parabens in mixture, to ensure optimal antimicrobial 
activities and acceptable solubility (Charnock and Finsrud 2007, Güzel Bayülken and Tüylü 2019, Soni et al. 2005, Kapalavavi et al. 2014, Giordano et al. 1999, Perlovich et al. 2005).

The results of our study are in agreement with numerous toxicological studies on parabens mutagenicity, genotoxicity and carcinogenicity, which often present ambiguous or warning conclusions. Potential genotoxicity and carcinogenicity has frequently been attributed to parabens, e.g. paraben esters have been reported to be detected in breast tissue biopsies, and antiperspirants have been suggested to be the source (Darbre et al. 2004). However, the risk assessment for humans has become highly challenging, as inconclusive or contradictory results have been demonstrated by numerous studies in vivo and in vitro or in combined test batteries (e.g., Tayama et al. 2008, Roszak et al. 2017, Barr et al. 2012, Fransway et al. 2019, Soni et al. 2005, Kang et al. 2013b, Darbre and Harvey 2008, Kim et al. 2020, Bilal and Iqbal 2019). Official scientific opinions summarize in their studies that the use of parabens is safe for human health as parabens are metabolised to benzoic acid in the human body and excreted in the urine, with benzoic acid being practically free of toxic effects in numerous tests and unlikely to interfere with chromosomes (SCF 1994, SCCP 2011, SCCP 2013). The results of our study indicate that genotoxicity testing should be strictly interpreted exclusively for the specific in vitro test system used in the bioassay, and standard bioavailability of the substance has to be thoroughly ensured. Moreover, as the genotoxicity of parabens is metabolism-dependent, a most relevant MAS should be included. With regard to the above limitations and observations of in vitro bioassays, our aim is to implement more in vitro methods based on human relevant cells and tissues into our laboratory, to achieve a sufficient battery of non-animal toxicological methods.

\section{Conflict of Interest}

There is no conflict of interest.

\section{Acknowledgements}

Supported by ERDF/ESF project "International competitiveness of NIPH in research, development and education in alternative toxicological methods" (No.CZ.02.1.01/0.0/0.0/16_019/0000860).

\section{References}

ALÉPÉE N, BAHINSKI A, DANESHIAN M, DE WEVER B, FRITSCHE E, GOLDBERG A, HANSMANN J, HARTUNG T, HAYCOCK J, HOGBERG H, HOELTING L, KELM JM, KADEREIT S, MCVEY E, LANDSIEDEL R, LEIST M, LÜBBERSTEDT M, NOOR F, PELLEVOISIN C, PETERSOHN D, PFANNENBECKER U, REISINGER K, RAMIREZ T, ROTHEN-RUTISHAUSER B, SCHÄFER-KORTING M, ZEILINGER K, ZURICH MG: t4 workshop report: State-of-the-art of 3D cultures (organs-on-a-chip) in safety testing and pathophysiology. ALTEX 31: 441-477, 2014. https://doi.org/10.14573/altex1406111

ALLEMANG A, MAHONY C, LESTER C, PFUHLER S: Relative potency of fifteen pyrrolizidine alkaloids to induce DNA damage as measured by micronucleus induction in HepaRG human liver cells. Food Chem Toxicol 121: 72-81, 2018. https://doi.org/10.1016/j.fct.2018.08.003

ANDERSEN ME, BETTS K, DRAGAN Y, FITZPATRICK S, GOODMAN JL, HARTUNG T, HIMMELFARB J, INGBER DE, JACOBS A, KAVLOCK R, KOLAJA K, STEVENS JL, TAGLE D, LANSING TAYLOR D, THROCKMORTON D: Developing microphysiological systems for use as regulatory tools - challenges and opportunities. ALTEX 31: 364-367, 2014. https://doi.org/10.14573/altex.1405151

BARR L, METAXAS G, HARBACH CA, SAVOY LA, DARBRE PD: Measurement of paraben concentrations in human breast tissue at serial locations across the breast from axilla to sternum. J Appl Toxicol 32: 219-232, 2012. https://doi.org/10.1002/jat.1786

BEKEN S, KASPER P, VAN DER LAAN JW: Regulatory acceptance of alternative methods in the development and approval of pharmaceuticals. Adv Exp Med Biol 856: 33-64, 2016. https://doi.org/10.1007/978-3-319-33826$\underline{2} 3$

BENIGNI R, BOSSA C, TCHEREMENSKAIA O, BATTISTELLI C L, CRETTAZ P: The new ISSMIC database on in vivo micronucleus and its role in assessing genotoxicity testing strategies. Mutagenesis 27: 87-92, 2012. https://doi.org/10.1093/mutage/ger064

BHAGAT J: Combinations of genotoxic tests for the evaluation of group 1 IARC carcinogens. J Appl Toxicol 38 : 81-99, 2018. https://doi.org/10.1002/jat.3496 
BILAL M, IQBAL HMN: An insight into toxicity and human-health-related adverse consequences of cosmeceuticals A review. Sci Total Environ 670: 555-568, 2019. https://doi.org/10.1016/j.scitotenv.2019.03.261

BORTOLUZZI MC, CAMPAGNOLI EB, MILAN JR, REINHEIMER A, MASSON M, CAPELLA DL: Frequency of micronucleus in oral epithelial cells after exposure to mate-tea in healthy humans. Med Oral Patol Oral Cir Bucal 19: 345-349, 2014. https://doi.org/10.4317/medoral.19570

BOWEN D, WHITWELL JH, LILLFORD L, HENDERSON D, KIDD D, MCGARRY S, PEARCE G, BEEVERS C, KIRKLAND DJ: Evaluation of a multi-endpoint assay in rats, combining the bone-marrow micronucleus test, the comet assay and the flow-cytometric peripheral blood micronucleus test. Mutat Res 722: 7-19, 2011. https://doi.org/10.1016/j.mrgentox.2011.02.009

CERVENA T, ROSSNEROVA A, SIKOROVA J, BERANEK V, VOJTISEK-LOM M, CIGANEK M, TOPINKA J, ROSSNER P: DNA damage potential of engine emissions measured in vitro by micronucleus test in human bronchial epithelial cells. Basic Clin Pharmacol Toxicol 121: 102-108, 2017. https://doi.org/10.1111/bcpt.12693

CHAMANZA R, WRIGHT JA: A review of the comparative anatomy, histology, physiology and pathology of the nasal cavity of rats, mice, dogs and non-human primates. Relevance to inhalation toxicology and human health risk assessment. J Comp Pathol 153: 287-314, 2015. https://doi.org/10.1016/j.jcpa.2015.08.009

CHAUNG W, MI L-J, BOORSTEIN RJ: The p53 status of Chinese hamster V79 cells frequently used for studies of DNA damage and DNA repair. Nucleic Acid Res 25: 992-994, 1997. https://doi.org/10.1093/nar/25.5.992

CHARNOCK C, FINSRUD T: Combining esters of para-hydroxy benzoic acid (parabens) to achieve increased antimicrobial activity. J Clin Pharm Ther 32: 567-572, 2007. https://doi.org/10.1111/j.1365-2710.2007.00854.x

CIOMS: International Ethical Guidelines for Health-related Research Involving Humans, 2016. https://cioms.ch/wpcontent/uploads/2017/01/WEB-CIOMS-EthicalGuidelines.pdf.

COLEMAN K, DAI X, DENG X, LAKEHAL F, TANG X: Medical device biocompatibility evaluation: An industry perspective. In: Biocompatibility and Performance of Medical Devices. J Boutrand (ed.), Cambridge, UK: Woodhead Publishing Ltd, 2012. https://doi.org/10.1533/9780857096456.2.201

COM: Guidance on a Strategy for genotoxicity Testing and mutagenic hazard assessment of Chemical substances. Committee on Mutagenicity of Chemicals in Food, Consumer Products And the Environment (COM), 2011. http://www.iacom.org.uk/publications/documents/StrategyGuidanceCOMconsultation3.pdf.

COMBES RD, BALLS M: The Three Rs-opportunities for improving animal welfare and the quality of scientific research. Altern Lab Anim 42: 245-259, 2014. https://doi.org/10.1177/026119291404200406

CORVI R, ALBERTINI S, HARTUNG T, HOFFMAN S, MAURICI D, PFUHLER S, BENTHEM J, VANPARYS P: ECVAM retrospective validation of in vitro micronucleus test (MNT). Mutagenesis 23: 271-283, 2008. https://doi.org/10.1093/mutage/gen010

COX JA, FELLOWS MD, HASHIZUME T, WHITE PA: The utility of metabolic activation mixtures containing human hepatic post-mitochondrial supernatant (S9) for in vitro genetic toxicity assessment. Mutagenesis 31: 117-130, 2016. https://doi.org/10.1093/mutage/gev082

CRETON S, DEWHURST IC, EARL LK, GEHEN SC, GUEST RL, HOTCHKISS JA, INDANS I, WOOLHISER MR, BILLINGTON R: Acute toxicity testing of chemicals-opportunities to avoid redundant testing and use alternative approaches. Crit Rev Toxicol 40: 50-83, 2010. https://doi.org/10.3109/10408440903401511

DAL NEGRO G, VANDIN L, BONATO M, SCIUSCIO D: Toward refinement of the colony-forming unitgranulocyte/macrophage clonogenic assay: inclusion of a metabolic system. Toxicol in vitro 20: 743-749, 2006. https://doi.org/10.1016/j.tiv.2005.10.016

DARBRE PD, ALJARRAH A, MILLER WR, COLDHAM NG, SAUER MJ, POPE GS: Concentrations of parabens in human breast tumours. J Appl Toxicol 24: 5-13, 2004. https://doi.org/10.1002/jat.958

DARBRE PD, HARVEY PW: Paraben esters: review of recent studies of endocrine toxicity, absorption, esterase and human exposure, and discussion of potential human health risks. J Appl Toxicol 28: 561-578, 2008. https://doi.org/10.1002/jat.1358 
DEARFIELD KL, THYBAUD V, CIMINO MC, CUSTER L, CZICH A, HARVEY JS, HESTER S, KIM JH, KIRKLAND D, LEVY DD, LORGE E, MOORE MM, OUÉDRAOGO-ARRAS G, SCHULER M, SUTER W, SWEDER K, TARLO K, VAN BENTHEM J, VAN GOETHEM F, WITT KL: Follow-up actions from positive results of in vitro genetic toxicity testing. Environ Mol Mutagen 52: 177-204, 2011. https://doi.org/10.1002/em.20617

De BOECK M, VAN der LEEDE B, VAn GOETHEM F, De SMEDT A, STEEMANS M, A. L, VANPARYS P: Flow cytometric analysis of micronucleated reticulocytes: Time- and dose dependent response of known mutagens in mice, using multiple blood sampling. Environ Molec Mutagen 46: 30-42, 2005. https://doi.org/10.1002/em.20127

DERTINGER SD, TOROUS DK, HAYASHI M, MACGREGOR JT: Flow cytometric scoring of micronucleated erythrocytes: an efficient platform for assessing in vivo cytogenetic damage. Mutagenesis 26: 139-145, 2011. https://doi.org/10.1093/mutage/geq055

Directive 2010/63/EU of the European Parliament and the Council of 22 September 2010 on the protection of animals used for scientific purposes. Official J EU 276: 33-79, 2010.

EC, 2008. COUNCIL REGULATION (EC) No 440/2008 of 30 May 2008 laying down test methods pursuant to Regulation (EC) No 1907/2006 of the European Parliament and of the Council on the Registration, Evaluation, Authorisation and Restriction of Chemicals (REACH).

EC, 2009. COUNCIL REGULATION (EC) No 1223/2009 of the European Parliament and of the Council of 30 November 2009 on cosmetic products (recast). Official Journal L 342, 2009, p.59.

ECHA, 2017. Report on Non-animal approaches - Current status of regulatory applicability under the REACH, CLP and Biocidal Products regulations. https://echa.europa.eu/documents/10162/22931011/ non_animal_approcches_en.pdf/87ebb68f-2038-f597-fc33-f4003e9e7d7d.

ECVAM, 1992. DB-ALM Protocol No 46: BALB/c 3T3 Neutral Red Uptake (NRU) Cytotoxicity Test. http://cidportal.jrc.ec.europa.eu/ftp/jrc-opendata/EURLECVAM/datasets/DBALM/LATEST/online/DBALM_docs/46_P_BALBc \%203T3\%20Neutral \%20Red \%20 Uptake \%20(NRU) \%20Cytotoxicity \%20Test.pdf

EFSA 2011 (European Food Safety Authority): Scientific opinion on genotoxicity testing strategies applicable to food and feed safety assessment. EFSA Journal 2379: 1-68, 2011.

EFSA 2012: Scientific opinion on genotoxicity testing strategies applicable to food and feed safety assessment https://efsa.onlinelibrary.wiley.com/doi/epdf/10.2903/j.efsa.2011.2379. https://doi.org/10.2903/j.efsa.2011.2379

EFSA 2018: Statement on Genotoxicity assessment of chemical mixtures. https://efsa.onlinelibrary.wiley.com/doi/epdf/10.2903/j.efsa.2019.5519 https://doi.org/10.2903/j.efsa.2019.5519

FLÜCKIGER-ISLER S, BAUMEISTER M, BRAUN K, GERVAIS V, HASLER-NGUYEN N, REIMANN R, VAN GOMPEL J, WUNDERLICH HG, ENGELHARDT G: Assessment of the performance of the Ames II assay: a collaborative study with 19 coded compounds. Mutat Res 558: 181-197, 2004. https://doi.org/10.1016/j.mrgentox.2003.12.001

FOWLER P, SMITH K, YOUNG J, JEFFREY L, KIRKLAND D, PFUHLER S, CARMICHAEL P: Reduction of misleading ("false") positive results in mammalian cell genotoxicity assays. I. Choice of cell type. Mutat Res 742: 11-25, 2012. https://doi.org/10.1016/j.mrgentox.2011.10.014

FRANSWAY AF, FRANSWAY PJ, BELSITO DV, YIANNIAS JA: Paraben Toxicology. Dermatitis 30: 32-45, 2019. https://doi.org/10.1097/DER.0000000000000428

GIANNOTTI E, VANDIN L, REPETO P, COMELLI R: A comparison of the in vitro Comet assay with the in vitro chromosome aberration assay using whole human blood or Chinese hamster lung cells: validation study using a range of novel pharmaceuticals. Mutagenesis 17: 163-170, 2002. https://doi.org/10.1093/mutage/17.2.163

GIORDANO F, BETTINI R, DONINI C, GAZZANIGA A, CAIRA MR, ZHANG GG, GRANT DJ: Physical properties of parabens and their mixtures: solubility in water, thermal behavior, and crystal structures. J Pharm Sci 88: 1210-1216, 1999. https://doi.org/10.1021/js9900452 
GÜZEL BAYÜLKEN D, AYAZ TÜYLÜ B, SINAN H, SIVAS H: Investigation of genotoxic effects of paraben in $\begin{array}{lllllll}\text { cultured human lymphocytes. Drug Chem Toxicol 42: } & \text { 349-356, } 2019 .\end{array}$ https://doi.org/10.1080/01480545.2017.1414834

GÜZEL BAYÜLKEN D, AYAZ TÜYLÜ B: In vitro genotoxic and cytotoxic effects of some paraben esters on human $\begin{array}{llllll}\text { peripheral lymphocytes. Drug Chem } & \text { Toxicol } & \text { 42: }\end{array}$ https://doi.org/10.1080/01480545.2018.1457049

HE X, TOTH TL: In vitro culture of ovarian follicles from Peromyscus. Semin Cell Dev Biol 61: 140-149, 2017. https://doi.org/10.1016/j.semcdb.2016.07.006

HONG YH, JEON HL, KO KY, KIM J, YI JS, AHN I, KIM TS, LEE JK: Assessment of the predictive capacity of the optimized in vitro comet assay using HepG2 cells. Mutat Res 827: 59-67, 2018. https://doi.org/10.1016/j.mrgentox.2018.01.010

JIRAVOVA J, TOMANKOVA KB, HARVANOVA M, MALINA L, MALOHLAVA J, LUHOVA L, PANACEL A, MANISOVA B, KOLAROVA H: The effect of silver nanoparticles and silver ions on mammalian and plant cells in vitro. Food Chem Toxicol 96: 50-61, 2016. https://doi.org/10.1016/j.fct.2016.07.015

JOSSÉ R, ROGUE A, LORGE E, GUILlOUZO A: An adaptation of the human HepaRG cells to the in vitro micronucleus assay. Mutagenesis 27: 295-304, 2012. https://doi.org/10.1093/mutage/ger076

JYOTI S, KHAN S, AFZAL M, SIDDIQUE YH: Micronucleus investigation in human buccal epithelial cells of gutkha users. Adv Biomed Res 1: 35, 2012. https://doi.org/10.4103/2277-9175.100128

JYOTI S, SIDDIQUE YH, KHAN S, NAZ F, RAHUL, ALI F: Effect on micronucleus frequency and DNA damage in buccal epithelial cells of various factors among pan masala and gutkha chewers. Oral Science International 12: 9-14, 2015. https://doi.org/10.1016/S1348-8643(14)00030-5

KANG SH, KWON JY, LEE JK, SEO YR: Recent advances in in vivo genotoxicity testing: Prediction of carcinogenic potential using comet and micronucleus assay in animal models. J Cancer Prev 18: 277-288, 2013a. https://doi.org/10.15430/JCP.2013.18.4.277

KANG S, KIM S, PARK J, KIM HJ, LEE J, CHOI G, CHOI S, KIM S, KIM SY, MOON HB, KIM S, KHO YL, CHOI $\mathrm{K}$ : Urinary paraben concentrations among pregnant women and their matching newborn infants of Korea, and the association with oxidative stress biomarkers. Sci Total Environ 461-462: 214-221, 2013b. https://doi.org/10.1016/j.scitotenv.2013.04.097

KAPALAVAVI B, ANKNEY J, BAUCOM M, YANG Y: Solubility of parabens in subcritical water. J Chem Eng 59: 912-916, 2014. https://doi.org/10.1021/je4010883

KAWAGUCHI S, NAKAMURA T, YAMAMOTO A, HONDA G, SASAKI YF: Is the comet assay a sensitive procedure for detecting genotoxicity? J Nucleic Acids 541050, 2010. https://doi.org/10.4061/2010/541050

KERECMAN MD, GOLDBERG AM, POTH A, WOLF MF, CARRAWAY J, MCKIM J, COLEMAN KP, HUTCHINSON R, BROWN R, KRUG HF, BAHINSKI A, HARTUNG T: From in vivo to in vitro: The medical device testing paradigm shift. ALTEX 34: 479-500, 2017. https://doi.org/10.14573/altex.1608081

KIM BS, MARGOLIN BH: Prediction of rodent carcinogenicity utilizing a battery of in vitro and In vivo genotoxicity tests. Environ Mol Mutagen 34: 297-304, 1999. https://doi.org/10.1002/(SICI)10982280(1999)34:4<297::AID-EM11>3.0.CO;2-Z

KIM MJ, KIM CH, AN MJ, LEE JH, SHIN GS, SONG M, KIM JW: Ethylparaben induces apoptotic cell death in human placenta BeWo cells via the Caspase-3 pathway. Anim Cells Syst 24: 34-43, 2020. https://doi.org/10.1080/19768354.2020.1711804

KIMURA A, MIYATA A, HONMA M: A combination of in vitro comet assay and micronucleus test using human lymphoblastoid TK6 cells. Mutagenesis 28: 583-590, 2013. https://doi.org/10.1093/mutage/get036

KIRKLAND DJ, AARDEMA M, HENDERSON L, MÜLLER L: Evaluation of the ability of a battery of 3 In vitro genotoxicity tests to discriminate rodent carcinogens and non-carcinogens. I. Sensitivity, specificity and relative predictivity, Mutat Res 584: 1-256, 2005. https://doi.org/10.1016/j.mrgentox.2005.02.004 
KIRKLAND DJ, PFUHLER S, TWEATS D, AARDEMA M, CORVI R, DARROUDI F, ELHAJOUJI A, GLATT H, HASTWELL P, HAYASHI M, KASPER P, KIRCHNER S, LYNCH A, MARZIN D, MAURICI D, MEUNIER JR, MÜLLER L, NOHYNEK G, PARRY J, PARRY E, THYBAUD V, TICE R, VAN BENTHEM J, VANPARYS P, WHITE P: How to reduce false positive results when undertaking in vitro genotoxicity testing and thus avoid unnecessary follow-up animal tests: Report of an ECVAM Workshop. Mutat Res 628: 31-55, 2007. https://doi.org/10.1016/j.mrgentox.2006.11.008

KIRKLAND DJ, REEVE L, GATEHOUSE D, VANPARYS P: A core in vitro genotoxicity battery comprising the Ames test plus the in vitro micronucleus test is sufficient to detect rodent carcinogens and in vivo genotoxins. Mutat Res 721: 27-73, 2011. https://doi.org/10.1016/j.mrgentox.2010.12.015

KIRSCH-VOLDERS M, DECORDIER I, ELHAJOUJI A, PLAS G, AARDEMA MJ, FENECH M: In vitro genotoxicity testing using the micronucleus assay in cell lines, human lymphocytes and 3D human skin models. Mutagenesis 26: 177-184, 2011. https://doi.org/10.1093/mutage/geq068

MADRIGAL-BUJAIDAR E, MADRIGAL-SANTILLAN E, ALVAREZ-GONZALEZ I, BAEZ R, MARQUEZ P: Micronuclei induced by imipramine and desipramine in mice: a subchronic study. Bas Clinic Pharmacol Toxicol 103: 569-573, 2008. https://doi.org/10.1111/j.1742-7843.2008.00328.x

MARX U, ANDERSSON TB, BAHINSKI A, BEILMANN M, BEKEN S, CASSEE FR, CIRIT M, DANESHIAN M, FITZPATRICK S, FREY O, GAERTNER C, GIESE C, GRIFFITH L, HARTUNG T, HERINGA MB, HOENG J, DE JONG WH, KOJIMA H, KUEHNL J, LEIST M, LUCH A, MASCHMEYER I, SAKHAROV D, SIPS AJ, STEGER-HARTMANN T, TAGLE DA, TONEVITSKY A, TRALAU T, TSYB S, VAN DE STOLPE A, VANDEBRIEL R, VULTO P, WANG J, WIEST J, RODENBURG M, ROTH A: Biology-inspired microphysiological system approaches to solve the prediction dilemma of substance testing. ALTEX 33: 272-321, 2016. https://doi.org/10.14573/altex.1603161

MCCARRICK S, CUNHA V, ZAPLETAL O, VONDRÁČEK J, DREIJ K: In vitro and in vivo genotoxicity of oxygenated polycyclic aromatic hydrocarbons. Environ Pollut 246: 678-687, 2019. https://doi.org/10.1016/j.envpol.2018.12.092

MORITA T, ASANO N, AWOGI T, SASAKI YF, SATO S, SHIMADA H, WAKATA A, SOFUNI T, HAYASHI M: Evaluation of the rodent micronucleus assay in the screening of IARC carcinogens (groups 1, 2A and 2B): The summary report of the 6th collaborative study by CSGMT/JEMS·MMS. Mutat Res 389: 3-122, 1997. https://doi.org/10.1016/S1383-5718(96)00070-8

MORITA T, HAMADA S, MASUMURA K, WAKATA A, MANIWA J, TAKASAWA H, HONMA M: Evaluation of the sensitivity and specificity of in vivo erythrocyte micronucleus and transgenic rodent gene mutation tests to detect rodent carcinogens. Mutat Res 802: 1-29, 2016. https://doi.org/10.1016/j.mrgentox.2016.03.008

MOSMANN T: Rapid colorimetric assay for cellular growth and survival: Application to proliferation and cytotoxicity assays. J Immunol Methods 65: 55-63, 1983.https://doi.org/10.1016/0022-1759(83)90303-4

MOWAT V, ALEXANDER DJ, PILLING AM: A comparison of rodent and nonrodent laryngeal and tracheal bifurcation sensitivities in inhalation toxicity studies and their relevance for human exposure. Toxicol Pathol 45: 216-222, 2017. https://doi.org/10.1177/0192623316678695

NESSLANY F: The current limitations of in vitro genotoxicity testing and their relevance to the in vivo situation. Food Chem Toxicol 106(Pt B): 609-615, 2017. https://doi.org/10.1016/j.fct.2016.08.035

NISHIMUTA H, NAKAGAWA T, NOMURA N, YABUKI M: Species differences in hepatic and intestinal metabolic activities for 43 human cytochrome P450 substrates between humans and rats or dogs. Xenobiotica 43: 948-955, 2013. https://doi.org/10.3109/00498254.2013.787155

NORPPA H, BONASSI S, HANSTEEN I-L, HAGMAR L, STRÖMBERG U, RÖSSNER P, LAZUTKA J: Chromosomal aberrations and SCEs as biomarkers of cancer risk. Mutat Res 600: 37-45, 2006. https://doi.org/10.1016/j.mrfmmm.2006.05.030

OECD (1997): OECD Guideline for testing of chemicals - Guideline 471: Bacterial Reverse Mutation Test. Organization for Economic Cooperation and Development, Paris, adopted 26 May 1983, last updated 21 July 1997.

https://www.oecd.org/general/searchresults/?q=oecd \%20471\&cx=012432601748511391518:xzeadub0b0a\&c of=FORID: $11 \&$ ie $=$ UTF-8 
OECD (2015): Guidance Document on Revisions to OECD Genetic Toxicology Test Guidelines. Aug 31, 2015, https://www.oecd.org/chemicalsafety/testing/Genetic \%20Toxicology \%20Guidance \%20Document \%20Aug $\% 2031 \% 202015 . p d f$

OECD (2016a), Test No. 473: In vitro Mammalian Chromosomal Aberration Test, OECD Guidelines for the Testing of Chemicals, Section 4, OECD Publishing, Paris. https://doi.org/10.1787/9789264264649-en

OECD (2016b), Test No. 476: In vitro Mammalian Cell Gene Mutation Tests using the Hprt and xprt genes, OECD Guidelines for the Testing of Chemicals, Section 4, OECD Publishing, Paris. https://doi.org/10.1787/9789264264809-en

OECD (2016c), Test No. 487: In vitro Mammalian Cell Micronucleus Test, OECD Guidelines for the Testing of Chemicals, Section 4, OECD Publishing, Paris. https://doi.org/10.1787/9789264264861-en

OECD (2016d), Test No. 489: In vivo Mammalian Alkaline Comet Assay, OECD Guidelines for the Testing of Chemicals, Section 4, OECD Publishing, Paris. https://doi.org/10.1787/9789264264885-en

OECD (2016e), Test No. 490: In vitro Mammalian Cell Gene Mutation Tests Using the Thymidine Kinase Gene, OECD Guidelines for the Testing of Chemicals, Section 4, OECD Publishing, Paris. https://doi.org/10.1787/9789264264908-en

OECD (2017), Overview on genetic toxicology TGs, OECD Series on Testing and Assessment, No. 238, OECD Publishing, Paris. https://doi.org/10.1787/9789264274761-en

OESCH F, FABIAN E, LANDSIEDEL R: Xenobiotica-metabolizing enzymes in the lung of experimental animals, man and in human lung models. Arch Toxicol 93: 3419-3489, 2019. https://doi.org/10.1007/s00204-019-02602-7

PARTON JW, HOFFMAN WP, GARRIOTT ML: Validation of an automated image analysis micronucleus scoring system. Mutat Res 370: 65-73, 1996. https://doi.org/10.1016/S0165-1218(96)90128-7

PERLOVICH GL, RODIONOV SV, BAUER-BRANDL A: Thermodynamics of solubility, sublimation and solvation processes of parabens. Eur J Pharm Sci 24(1): 25-33, 2005. https://doi.org/10.1016/j.ejps.2004.09.007

PFUHLER S, KIRKLAND D, HAYASHI M, VANPARYS P, CARMICHAEL P, DERTINGER S, EASTMOND D, ELHAJOUJI A, KRUL C, ROTHFUSS A, SCHOENING G, SMITH A, SPEIT G, THOMAS C, VAN BENTHEM J, CORVI R: Reduction of use of animals in regulatory genotoxicity testing: Identification and implementation opportunities - Report from an ECVAM workshop. Mutat Res 680: 31-42, 2009. https://doi.org/10.1016/j.mrgentox.2009.09.002

PFUHLER S, PIROW R, DOWNS TR, HAASE A, HEWITT N, LUCH A, MERKEL M, PETRICK C, SAID A, SCHÄFER-KORTING M, REISINGER K: Validation of the 3D reconstructed human skin Comet assay, an animal-free alternative for following-up positive results from standard in vitro genotoxicity assays. Mutagenesis 20: 1-17, 2020a. https://doi.org/10.1093/mutage/geaa009

PFUHLER S, VAN BENTHEM J, CURREN R, DOAK SH, DUSINSKA M, HAYASHI M, HEFLICH RH, KIDD D, KIRKLAND D, LUAN Y, OUEDRAOGO G, REISINGER K, SOFUNI T, VAN ACKER F, YANG Y, CORVI R: Use of in vitro 3D tissue models in genotoxicity testing: Strategic fit, validation status and way forward. Report of the working group from the 7th International Workshop on Genotoxicity Testing (IWGT). Mutat Res 1: 850-851, 2020b. https://doi.org/10.1016/j.mrgentox.2020.503135

PHALEN RF, OLDHAM MJ, WOLFF RK: The relevance of animal models for aerosol studies. J Aerosol Med Pulm Drug Deliv 21: 113-124, 2008. https://doi.org/10.1089/jamp.2007.0673

PUERTO M, PRIETO AI, MAISANABA S, GUTIÉRREZ-PRAENA D, MELLADO-GARCÍ: Cylindrospermopsin by a battery of in vitro tests. Food Chem Toxicol 121: 413-422, 2018. https://doi.org/10.1016/j.fct.2018.09.013

RANGANATHA R, CHAKRAVARTHY S, SUKUMARAN SK: High-throughput approaches for genotoxicity testing in drug development: recent advances. J High Trough Sreen 6: 1-12, 2016. https://doi.org/10.2147/IJHTS.S70362

RECIO L, HOBBS C, CASPARY W, WITT KL: Dose-response assessment of four genotoxic chemicals in a combined mouse and rat micronucleus and comet assay protocol. J Toxicol Sci 35: 149, 2010. https://doi.org/10.2131/jts.35.149 
REISINGER K, BLATZ V, BRINKMANN J, DOWNS T, FISCHER A, HENKLER F, HOFFMANN S, KRUL C, LIEBSCH M, LUCH A, PIROW R, REUS A, SCHULZ M, PFUHLER S: Validation of the 3D Skin Comet assay using full thickness skin models: Transferability and reproducibility. Mutat Res Genet Toxicol Environ Mutagen 827: 27-41, 2018. https://doi.org/10.1016/j.mrgentox.2018.01.003

ROSSINI GP, HARTUNG T: Towards tailored assays for cell-based approaches to toxicity testing. ALTEX 29: 359- 372, 2012. https://doi.org/10.14573/altex.2012.4.359

ROSZAK J, DOMERADZKA-GAJDA K, SMOK-PIENIĄŻEK A, KOZAJDA A, SPRYSZYŃSKA S, GROBELNY J, STĘPNIK M: Genotoxic effects in transformed and nontransformed human breast cell lines after exposure to silver nanoparticles in combination with aluminium chloride, butylparaben or di-n-butylphthalate. Toxicol In vitro 45: 181-193, 2017. https://doi.org/10.1016/j.tiv.2017.09.003

ROY S, KULKARNI R, HEWITT NJ, AARDEMA MJ: The EpiDerm ${ }^{\mathrm{TM}}$ 3D human reconstructed skin micronucleus (RSMN) assay: Historical control data and proof of principle studies for mechanistic assay adaptations. Mutat Res 805: 25-37, 2016. https://doi.org/10.1016/j.mrgentox.2016.05.010

RUSSELL WMS, BURCH RL: The Principles of Humane Experimental Technique. UK: Methuen, London, 1959, pp 238.

SCCP, 2011. Scientific Committee on Consumer Products (SCCP). Opinion on parabens, COLIPA No P82. European Commission; Directorate-General for Health \& Consumers. 2011. Date Accessed 2-13-2012. Report No. SCCS/1348/10. pp. 1-36.

https://ec.europa.eu/health/scientific_committees/consumer_safety/docs/sccs_o_041.pdf

SCCP, 2013. Scientific Committee on Consumer Products (SCCP). Opinion on parabens; Updated request for a scientific opinion on propyl and butylparaben, COLIPA No P82. European Commission. 2013. Report No. SCCS/1514/13. http://ec.europa.eu/health/scientific_committees/consumer_safety/docs/sccs_o_132.pdf

SCF, 1994. Opinion on benzoic acid and its salts. Expressed on 24 February 1994. Reports of the Scientific Committee for Food, Thirty-Fifth Series. CEC, Luxembourg. pp. 33-39, 1994.

SHELBY M, ZEIGER E: Series: 'current issues in mutagenesis and carcinogenesis' no. 20 activity of human carcinogens in the Salmonella and rodent bone-marrow cytogenetics tests. Mutat Res 234: 257-261, 1990. https://doi.org/10.1016/0165-1161(90)90022-G

SOETEMAN-HERNÁNDEZ LG, JOHNSON GE, SLOB W: Estimating the carcinogenic potency of chemicals from the in vivo micronucleus test. Mutagenesis 31: 347-358, 2016. https://doi.org/10.1093/mutage/gev043

SONI MG, BURDOCK GA, TAYLOR SL, GREENBERG NA: Safety assessment of propyl paraben: a review of the published literature. Food Chem Toxicol 39: 513-532, 2001. https://doi.org/10.1016/S0278-6915(00)00162-9

SONI MG, CARABIN IG, BURDOCK GA: Safety assessment of esters of p-hydroxybenzoic acid (parabens). Food Chem Toxicol 43: 985-1015, 2005. https://doi.org/10.1016/j.fct.2005.01.020

STOLTZ D, POIRIER L, IRVING C, STICH H, WEISBURGER J, GRICE H: Evaluation of short-term tests for carcinogenicity. Toxicol Appl Pharmacol 29: 157-180, 1974. https://doi.org/10.1016/0041-008X(74)90054-4

STORER RD, KRAYNAK AR, MCKELVEY TW, ELIA MC, GOODROW TL, DELUCA JG: The mouse lymphoma L5178Y Tk+/- cell line is heterozygous for a codon 170 mutation in the p53 tumor suppressor gene. Mutat Res 373: 157-165, 1997. https://doi.org/10.1016/S0027-5107(96)00227-8

STYLES JA, CLARK H, FESTING MF, REW DA: Automation of mouse micronucleus genotoxicity assay by laser scanning cytometry. Cytometry 44: 153-155, 2001. https://doi.org/10.1002/10970320(20010601)44:2<153::AID-CYTO1095>3.0.CO;2-H

TAYAMA S, NAKAGAWA Y, TAYAMA K: Genotoxic effects of environmental estrogen-like compounds in CHO-K1 cells. Mutat Res 649: 114-125, 2008.

TICE RR, AGURELL E, ANDERSON D, BURLINSON B, HARTMANN A, KOBAYASHI H, MIYAMAE Y, ROJAS E, RYU JC, SASAKI YF: Single cell gel/comet assay: guidelines for in vitro and In vivo genetic toxicology testing. Environ Mol Mutagen 35: 206-221, 2000. https://doi.org/10.1002/(SICI)10982280(2000)35:3<206::AID-EM8>3.0.CO;2-J

TURKEZ H, ARSLAN ME, OZDEMIR O: Genotoxicity testing: progress and prospects for the next decade. Expert Opin Drug Metab Toxicol 13: 1089-1098, 2017. https://doi.org/10.1080/17425255.2017.1375097 
TWEATS DJ, BLAKEY D, HEFLICH RH, JACOBS A, JACOBSEN SD, MORITA T, NOHMI T, O'DONOVAN MR, SASAKI YF, SOFUNI T, TICE R: Report of the IWGT working group on strategies and interpretation of regulatory in vivo tests II. Identification of in vivo-only positive compounds in the bone marrow micronucleus test. Mutat Res 627: 92-105, 2007a. https://doi.org/10.1016/j.mrgentox.2006.10.006

TWEATS DJ, SCOTT AD, WESTMORELAND C, CARMICHAEL PL: Determination of genetic toxicity and potential carcinogenicity in vitro-challenges post the Seventh Amendment to the European Cosmetics Directive. Mutagenesis 22: 5-13, 2007b. https://doi.org/10.1093/mutage/gel052

VASQUEZ MZ: Combining the in vivo comet and micronucleus assays: A practical approach to genotoxicity testing and data interpretation. Mutagenesis 25: 187-199, 2010. https://doi.org/10.1093/mutage/gep060

WIECZERZAK M, NAMIEŚNIK J, KUDŁAK B: Genotoxicity of selected pharmaceuticals, their binary mixtures, and varying environmental conditions - study with human adenocarcinoma cancer HT29 cell line. Drug Chem Toxicol 4: 1-11, 2019. https://doi.org/10.1080/01480545.2018.1529783

WMA, 1964. WMA Declaration of Helsinki - Ethical Principles for Medical Research Involving Human Subjects. https://www.wma.net/policies-post/wma-declaration-of-helsinki-ethical-principles-for-medical-researchinvolving-human-subjects

WU Y, WANG G: Machine learning based toxicity prediction: from chemical structural description to transcriptome analysis. Int J Mol Sci 19: 2358, 2018. https://doi.org/10.3390/ijms19082358

XU J, MA M, PURCELL WM: Biochemical and functional changes of rat liver spheroids during spheroid formation and maintenance in culture: II. nitric oxide synthesis and related changes. J Cell Biochem 90: 1176-1185, 2003. https://doi.org/10.1002/jcb.10731 